\title{
You've Got Mail: Techniques To Increase Response Rates
}

Karen Oliphant, (E-mail: kjoliphant@optusnet.com.au), University of Sydney

Catherine Sutton-Brady, (E-mail: c.sutton-brady@econ.usyd.edu.au), University of Sydney

\begin{abstract}
While much research exists on the benefits of using postal surveys especially in B2B marketing, it is understood and almost universally accepted that postal surveys are synonymous with low response rates. The paper presents results from a study carried out within the wine industry in Australia where a variety of techniques were utilised to overcome the expected low response rates. The various methods that were implemented to test how response rates can be influenced include the accompaniment of the survey with a reply paid addressed envelope, a coversheet on University letterhead explaining the offer of results in return for completing the survey, pre-notification and reminders via e-mail and the drop and collect survey method. The findings are significant in that a combination of techniques was used on the dyad (buyer and supplier) which allowed for comparison of relative effectiveness and success of the techniques. A timeline used to test these techniques is presented and the subsequent influence is presented. This research provides valuable insights to academics who, because of various circumstances (inaccessibility, cost etc.), have no choice but to use postal surveys. It is interesting also that pre-notification by e-mail had a significant impact.
\end{abstract}

\section{INTRODUCTION}

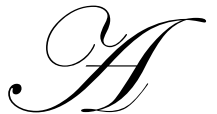

cademic research especially that undertaken in business and industrial markets has for much of its history relied upon postal surveys. Although nowadays with improvements in technology and the ubiquitous availability of email and internet access there has been a move towards on-line or email surveys, (Schaefer and Dillman 1998; Best and Krueger 2002; Shough and Yates 2002), many academics still rely heavily on the postal survey. This reliance may be partly on the difficulty of finding accurate e-mail listings for respondents (Shough and Yates 2002) and also due to the fact that many companies will not open attachments or use web links in e-mails for fear of triggering a virus. As a result many academics find that the easiest and most accessible method of reaching an industrial sample is a postal survey. However, having said this, much research has highlighted response rates as the major obstacle of this method. We will initially outline our rationale in this particular study for utilising a postal survey and secondly highlight some of the techniques used to increase response rates.

\section{NATURE OF THE STUDY UNDERTAKEN}

The aim of our study was to show how and to what extent Australian companies manage their business relationships. This research also specifically examined the buyer/supplier dyad to establish how buyers and suppliers manage their business relationships differently. The Australian Wine Industry was chosen to study in order to achieve the aims of this research. A total of 1600 surveys were sent by mail to businesses within the Wine Industry right across Australia. The buyers in this study are the wine producers and the suppliers include the wide variety of businesses that supply inputs to the wine industry.

The research instrument used for this study was an existing questionnaire that was developed and administered by Leek, et al, 2004. The use of this existing questionnaire facilitated the comparison of results from this study with the Leek, et al, 2004 study. It is also expected that it will also allow comparisons to be made with future research intended in this series. While the main reason the questionnaire was sent via post was to maintain consistency with the Leek, et al, (2004) study to enable comparison with it and future research in this series, the use of e-mail was 
considered to collect data, however, this would narrow the sampling frame as not all businesses use e-mail. Viruses and spam are also a concern regarding the response rates for e-mail surveys (Sills and Chunyan, 2002). Postal surveys are also beneficial when trying to gather information from busy and inaccessible people because they can complete it in their own time (Cooper, et al, 2001).

\section{EXPECTATIONS WITH REGARD TO RESPONSE RATES}

Erdogan and Baker (2002) have pointed out that one way to increase response rates is to carefully design the mail survey; however given that we were using an existing questionnaire for comparison purposes we had no say in the design of the questionnaire. Additionally the results from the Leek et al (2004) study showed disappointingly low response rates which meant that we were aware that response rates for our study may also be low. Erdogan and Baker (2002) state, that another way to increase response rates, is to increase the sample size, so that while the percentage may still be low, it will a percentage of a larger sample. This study was originally planned as a pilot study but given the views in the literature on the size of the sample it was decided to utilise the full mailing list available thus giving us a sample of 1600 respondents.

\section{USE OF A POSTAL SURVEY}

As previously pointed out we were striving to achieve comparisons with the Leek et al study of 2004 hence the mail survey was unavoidable. We needed consistency in instrument and method to allow for a true comparison. Additionally compared to other face to face methods, postal surveys incur relatively low costs which only include envelopes, printing and postal expenses (Cooper, et al, 2001). The postal survey also has the advantage of gathering data from a wide geographical area around Australia without incurring extra costs for increased geographical coverage. (Cooper, et al, 2001) The postal survey has also made total anonymity of the respondent possible (Cooper, et al, 2001). This ethical consideration is an important one in deciding to use postal surveys, especially since this study required respondents to discuss their relationships with either their buyers or suppliers and previous research by one of the authors has found that in these cases anonymity is crucial in achieving a response (Sutton-Brady 2001). The following section will examine the techniques utilised in an attempt to increase the response rate.

\section{REPLY PAID ENVELOPES}

The first decision made was to include a reply paid envelope with the questionnaire in an attempt to encourage response (Harris and Guffey, 1978). Research has been completed on the effect on response rates of using business reply paid envelopes versus regular stamped return envelope (Cox III, et al, 1974; Harris and Guffey, 1978; Yammarino, et al, 1991; Dillman, 2000). The general consensus in the literature is that putting real stamps on a reply paid envelopes improves response rates because it represents the researcher offering something of monetary value to the respondent. Cost benefit research has also been completed regarding various techniques, proposed to improve mail survey response rates (Newby, et al, 2003; Teitler, et al, 2003), which clearly show that while the existence of the stamps does have a psychological impact on respondents it is a very expensive way of achieving an increase. Thus it was decided that it was, more, cost-effective in this instant to send business reply paid envelopes instead of envelopes with actual stamps on them. Given expected low response rates it would have been too expensive to send 1600 surveys with stamps on them while using reply paid envelopes meant only the surveys returned incurred postal charges. .Realistically it was the only decision that could have been made for this study because postal surveys are synonymous with low response rates as evidenced by the multitude of research completed on improving mail survey response rates and the fact that the previous study that used the same questionnaire only gained an $8 \%$ response rate (Turley, 1999, Taylor, 1998; Kallis \& Giglierano, 1992; Armstrong, 1990; Whitley, 1985).

\section{COVER LETTER}

A cover letter was attached to the questionnaire. It explained the purpose of the study and confirmed the researcher's commitment to confidentiality of responses. Official University letterhead was used on the cover sheet as University sponsorship of research studies has been shown to improve response rates (Erdogan and Baker 2002; Dennis, 2003). An official University of Sydney e-mail address was also provided as contact details on the coversheet. 
The envelopes that were sent also had the University of Sydney emblem on them. Respondents within this letter were also assured of anonymity.

\section{OFFERING SURVEY RESULTS}

Research has been completed on whether response rates are improved by the offer of survey results to the respondents on completion of the survey (Cox III, et al, 1974). Mixed results have been published regarding the effectiveness of using this technique, for example, the issue of lost anonymity, which respondents may fear when having to disclose their identity to receive the results. The potential respondents were advised via the cover sheet that the survey results would be available as an incentive to complete the survey. Respondents had to identify themselves via e-mail if they desired the results, which maintained anonymity, as there was no connection between their details and the physical survey. A total of seven respondents requested the results via e-mail. Although this is a small response, it is possible that this technique had more of an influence than this suggests, for example, if people forgot to e-mail and request the results after completing the survey. It is also possible that offering something in return for completing the survey created goodwill and thus influenced the response rate.

\section{PRE-NOTIFICATION \& REMINDERS}

A slightly modified version of the cover letter was send via e-mail as a pre-notification of the study to suppliers only. Research has continually showed that notification prior to the arrival of surveys will improve response rates (Kanuk and Berenson, 1975; Fox, et al, 1988; Dillman, et al, 1995; Dillman, 1991; Dillman; 2000). The prenotification e-mail was specifically only e-mailed to suppliers to see if it influenced the response rate of the suppliers versus the buyers. A reminder was then also only sent to suppliers via e-mail one month after the survey arrived. Buyers were subsequently sent a reminder e-mail after the suppliers reminder in an attempt improve the buyers response rate Table A below outlines the timeline of these techniques and their expected influence on response rates based on supporting literature.

TABLE A:

TIMELINE OF TECHNIQUES USED TO INFLUENCE RESPONSE RATES

\begin{tabular}{|c|c|c|}
\hline Date & Technique & $\begin{array}{c}\text { Date Expected To Influence } \\
\text { Response Rates }\end{array}$ \\
\hline $27^{\text {th }}$ August 2004 & $\begin{array}{l}\text { Only the Suppliers were sent an e- } \\
\text { mail of the modified cover sheet to } \\
\text { notify them when the survey was } \\
\text { arriving and a description of what it } \\
\text { was for. }\end{array}$ & $\begin{array}{l}\text { Expected to increase response rates } \\
\text { of suppliers only when the survey } \\
\text { was delivered (Kanuk and } \\
\text { Berenson, 1975; Fox, et al, 1988; } \\
\text { Dillman, et al, 1995; Dillman, 1991; } \\
\text { Dillman; 2000) }\end{array}$ \\
\hline $15^{\text {th }}$ September 2004 & $\begin{array}{l}\text { Questionnaire was mailed to } \\
\text { potential respondents }\end{array}$ & N/A \\
\hline $15^{\text {th }}$ October 2004 & $\begin{array}{l}\text { Reminder to complete the survey } \\
\text { was sent via e-mail only to the } \\
\text { suppliers. }\end{array}$ & $\begin{array}{l}\text { Approx. a week after the e-mail } \\
(22 / 10 / 04) \text { to allow time to post the } \\
\text { survey back from around Australia. }\end{array}$ \\
\hline $26^{\text {th }}$ October 2004 & $\begin{array}{l}\text { Reminder to complete the survey } \\
\text { was sent via e-mail to the buyers. }\end{array}$ & $\begin{array}{l}\text { Approx. a week after the e-mail } \\
(2 / 11 / 04) \text { to allow time to post the } \\
\text { survey back from around Australia. }\end{array}$ \\
\hline
\end{tabular}

\section{DROP-AND-COLLECT-SURVEY METHOD}

The last technique used in an attempt to increase the response rates of the buyers and obtain an equal sample of both was a modified version of the drop-and-collect-survey method. A list of potential respondents was made from the original data base (all in close proximity for convenience). An attempt was made to directly contact all respondents by phone to notify them of the intended visit. This phone call was followed by personally visiting the wineries and dropping off new surveys to almost everyone. The various reasons for those who required another copy of the survey include: not receiving it, ownership changing resulting in surveys getting lost in the change, misplacing 
or disposing of them. The few respondents who said the survey would be ready to be picked up later that day were visited to collect the completed surveys.

\section{RESULTS}

The following Table B outlines the results from two of the techniques used to influence response rates.

TABLE B:

RESULTS FROM TECHNIQUES TO INFLUENCE RESPONSE RATES

\begin{tabular}{|l|l|l|l|}
\hline & $\begin{array}{l}\text { Buyers surveys sent back in } \\
\text { time period as a \% of total } \\
\text { buyers surveys sent back } \\
(27)\end{array}$ & $\begin{array}{l}\text { Suppliers surveys sent back } \\
\text { in time period as a \% of } \\
\text { total suppliers surveys sent } \\
\text { back. (52) }\end{array}$ & $\begin{array}{l}\text { Difference in \% between } \\
\text { buyers and suppliers surveys } \\
\text { sent back in each time } \\
\text { period }\end{array}$ \\
\hline $\begin{array}{l}\text { Surveys 1-19 sent back } \\
\text { before e-mail reminder to } \\
\text { suppliers }\end{array}$ & $3(11 \%)$ & $16(30 \%)$ & $\begin{array}{l}19 \% \text { less surveys were sent } \\
\text { back by buyers than } \\
\text { suppliers }\end{array}$ \\
\hline $\begin{array}{l}\text { Surveys 20-61 sent back } \\
\text { after e-mail reminder to } \\
\text { suppliers }\end{array}$ & $16(59 \%)$ & $26(50 \%)$ & $\begin{array}{l}9 \% \text { less surveys were sent } \\
\text { back by suppliers than } \\
\text { buyers }\end{array}$ \\
\hline $\begin{array}{l}\text { Surveys 62-79 sent back } \\
\text { after e-mail reminder to } \\
\text { buyers }\end{array}$ & $8(30 \%)$ & $10(19 \%)$ & $\begin{array}{l}11 \% \text { more surveys sent back } \\
\text { by buyers than suppliers }\end{array}$ \\
\hline
\end{tabular}

In the time period between sending e-mail pre-notification of the survey to the suppliers only and the next time period when reminders were sent to suppliers after the surveys had been delivered, $30 \%$ of total supplier responses were returned compared to only $11 \%$ of total buyer responses. That is $19 \%$ more surveys returned by suppliers than buyers in this time period which could be attributed to the influence from the pre-notification e-mail which was only sent to the suppliers. This result supports the literature that an e-mail to notify potential respondents of a survey before it arrives increases response rates (Dillman, et al, 1995; Dillman, 1991; Dillman; 2000).

In the next time period between sending e-mail reminders to suppliers and sending e-mail reminders to buyers, $59 \%$ of the total buyers' surveys returned were sent back compared to $50 \%$ of total suppliers' surveys sent back. Theory would suggest that the e-mail sent only to suppliers to remind them to send the survey back should result in a higher percentage of suppliers surveys being sent back compared to buyers. This was not the case. A possible reason for this may have been the considerable one month time period between the respondents receiving the survey and the e-mail reminder to the supplier. Another point to note is that $30 \%$ of the total supplier surveys sent back had already been returned thus the response rate after the first reminder would be expected to be reduced a certain amount.

After the buyers were sent an e-mail to remind them to return the survey, the buyers' response rate as a percentage of total buyers surveys sent back was higher than suppliers. Buyers returned $11 \%$ more surveys in this time period than suppliers. This supports the theory that a reminder to a respondent to complete a survey should increase response rates. It was, however, mentioned in the result immediately before this that a possible reason that suppliers did not have a higher percentage response rate than buyers after a reminder e-mail was sent only to suppliers was attributed to the one month time period from when the suppliers received their survey to when the reminders were sent. Having just suggested that the buyers' reminder e-mail did improve response rates this contradicts the reasons given for why the suppliers didn't have a higher response rate. There was a greater time between the buyers receiving their survey and their reminder. This e-mail contact was, however, the first contact with the buyers since the survey had been sent and thus may have had a larger influence on response rates than when the suppliers were sent a reminder e-mail because they also received a pre-notification regarding the arrival of the survey. 


\section{CONCLUSIONS}

This research has offered interesting findings regarding what methods can be used to improve the response rates of postal surveys in business and industrial markets. The various methods that were implemented to test how response rates can be influenced, include the accompaniment of the survey with a reply paid addressed envelope, a coversheet explaining the offer of results in return for completing the survey, pre-notification and reminders via e-mail and the drop and collect survey method. It is clear from our results that pre-notification is an excellent way to influence response rates. Additionally it was found that reminders appear to be more effective when it is the first email contact. It may also be more fruitful to include a copy of the questionnaire with the reminder as we did find when using the drop and collect method that many had lost or misplaced the original copy. We did give them the option to ask for another copy but this may have not been as effective as actually sending them one with the reminder, as many may not have taken the extra time and effort required to reply and ask for another copy.

Interestingly though while very attempt was made to influence response rates the overall response was disappointingly low and maybe in the case of this research the need is for a method other than postal survey to illicit a large enough sample. Some of the blame can be laid on the length of the questionnaire and some work will be done to shorten that while still maintaining the overall objectives of the study.

Future research could also investigate the impact of differing follow-up techniques and their effectiveness since this paper only looked at e-mail follow-up and drop and collect of the surveys.

\section{REFERENCES}

1. Armstrong, J.S., (1990) Class of mail does affect response rates to mailed questionnaires; evidence from meta-analysis, Journal of Market Research Society, 32(3), p. 469-472

2. Best, S.J. and Krueger, B. (2002) New approaches to assessing opinion: The prospects for electronic mail surveys, International Journal of Public Opinion Research, Spring 14(1) p. 73-92

3. Cooper, D.R. and Emory, C.W., (1995), Business Research Methods ( $5^{\text {th }}$ Edition), Irwin, Chicago.

4. Cooper, D.R. and Schindler, P.S., (2001), Business Research Methods. Seventh Edition, Irwin/McGraw-Hill, New York.

5. Cox III, E.P., Anderson, Jr., W.T, and Fulcher, D.G., (1974), Reappraising Mail Survey Response Rates, Journal of Marketing Research, 11(4), p. $413-418$.

6. Dennis, W.J., (2003), Raising response rates in mail surveys of small business owners: Results of an experiment, Journal of Small Business Management, 41(3), p. 278-295.

7. Dillman, D.A., (2000) Mail and Internet Surveys. The Tailored Design Method. Second Edition, John Wiley \& Sons Inc, New York.

8. Dillman, D.A., Clark, J.R., and Sinclair, M.A., (1995) How prenotice letters, stamped return envelopes, and reminder postcards affect mailback response rates for census questionnaires. Survey Methodology, 21, p. 1 7 - as cited in: Dillman, D.A., (2000) Mail and Internet Surveys. The Tailored Design Method. Second Edition, John Wiley \& Sons Inc, New York.

9. Dillman, D.A., (1991) The design and administration of mail surveys. Annual Review of Sociology, 50, p. 225-249.

10. Erdogan, B.Z. and Baker, M.J. (2002) Increasing mail survey response rates from an industrial population Industrial Marketing Management, 31, p. 65-73.

11. Fox, R.J., Crask, M.R., and Kim, J., (1988) Mail survey response rate: A Meta analysis of selected techniques for inducing response. Public Opinion Quarterly, 52(4), p. 467-491 - as cited in: Dillman, D.A., 2000, Mail and Internet Surveys. The Tailored Design Method. Second Edition, John Wiley \& Sons Inc, New York.

12. Goff, J., Harding, D., Shah, R., and Singer, M., (1998) A new way to reach small businesses, McKinsey Quarterly, 3, 172-177.

13. Harris, J.R. and Guffey, Jr., H.J., (1978) Questionnaire Returns: Stamps Versus Business Reply Envelopes Revisited, Journal of Marketing Research, 15(2), p. 290-294. 
14. Kanuk, L. and Berenson, C., (1975) Mail surveys and response rates: A literature review Journal of Marketing Research, 12(4), p. 400 - 453. - As cited in: Dillman, D.A., 2000, Mail and Internet Surveys. The Tailored Design Method. Second Edition, John Wiley \& Sons Inc, New York.

15. Leek, S., Turnbull, P.W., and Naude, P. (2004), A comparison of manufacturers and financial services suppliers' and buyers' use of relationship management methods, Industrial Marketing Management, Vol. 33, No. 3.

16. Newby, R., Watson, J., and Woodliff, D., (2003) SME Survey Methodology: Response Rates, Data Quality, and Cost Effectiveness, Entrepreneurship: Theory \& Practice, 29(2), p. 163-173

17. Schaefer, D.R. and Dillman, D.A. (1998) Development of a standard e-mail methodology: results of an experiment, Public opinion Quarterly, 62(3) p. 378-390.

18. Sills, S. and Chunyan, S., (2002) Innovations in Survey Research: An application of Web Surveys, Social Science Computer Review, 20, p. 22-30

19. Shough, S. and Yates, D., (2002) The advantages of an e-mail survey, Journal of Applied Business Research, 18(2) p. 37-45.

20. Sutton-Brady, C. and Cameron, R., (2001) Relationship Atmosphere: the final chapter Conference Proceedings, 17th Annual IMP Conference, Bath, U.K., September 2001.

21. Taylor, S., (1998) The effect of a preliminary notification letter on response to a postal survey of young people, Journal of the Marketing Research Society, 40(2), p. 165-173.

22. Ticehurst G.W. and Veal A.J., (1999), Business Research Methods: A Managerial Approach, Addison Wesley Longman Australia Pty Ltd.

23. Teitler, J.O., Reichman, N.E., and Sprachman, S., (2003)Cost and benefits of improving response rates for a hard-to-reach population, Public Opinion Quarterly, 67(1), p. 126-139.

24. Turley, S.K., (1999) A case of response rate success, Journal of Market Research Society, 41(3), p. 301-310.

25. Yammarino, F.J., Skinner, S.J., and Childers, T.I., (1991) Understanding mail survey response behavior; A meta-analysis, Public Opinion Quarterly, 55(4). P. 613-639. 